\title{
Articles
}

\section{Digital Multimodal Composition and Second Language Teacher Knowledge}

Nicole Schmidt

Before second language writing (SLW) teachers' digital practices can be supported, their needs must first be understood. To accomplish effective technologyenhanced instruction, SLW teachers must blend their knowledge of composition theory, second language acquisition, and multimodal composition technologies. However, many teachers struggle to do this, which highlights the need for research addressing the cognitive aspects that influence digital instruction. This case study reports on an investigation of three in-service university SLW teachers' Technological Pedagogical Content Knowledge (TPACK) during a digital reflective portfolio module. Data from an online survey, instructional content, classroom observations, and semistructured interviews were triangulated to uncover the nature of SLW teachers' TPACK, including which factors supported and constrained their use of technology. Findings suggest that pedagogical content knowledge played a dominant role in how the teachers used technology. The teachers' TPACK was enhanced by professional beliefs about the importance of multimodality and contextual factors involving institutional support and communities of practice. However, it was constrained by limited self-efficacy and pedagogical beliefs concerning the influence of technology on student learning and student engagement. This study contributes to a growing body of research on how to support language teachers in their digitally mediated practices.

Avant de pouvoir soutenir les pratiques numériques des enseignantes et enseignants d'expression écrite en langue seconde (SLW), il faut commencer par en comprendre les besoins. Pour être à même de dispenser efficacement un enseignement enrichi par la technologie, les enseignantes et enseignants d'expression écrite en langue seconde doivent amalgamer leurs connaissances dans les domaines de la théorie de la composition, de l'acquisition d'une langue seconde et des technologies de composition multimodale. Beaucoup d'enseignantes et d'enseignants, toutefois, arrivent mal à le faire, ce qui souligne le besoin de recherches sur les facteurs cognitifs qui ont une incidence sur l'enseignement numérique. La présente étude de cas fait état de recherches menées auprès de trois enseignants (un homme et deux femmes) d'expression écrite en langue seconde en cours de service au niveau universitaire dans le cadre TPACK (Technological Pedagogical Content Knowledge). Des données issues d'un sondage en ligne, un contenu pédagogique, des observations faites en salle de classe et des entrevues semi-structurées ont été triangulés 
pour lever le voile sur la nature des connaissances des enseignantes et enseignants d'expression écrite en langue seconde dans le cadre TPACK, y compris la question de savoir quels facteurs soutiennent ou restreignent leur recours à la technologie. Les constatations suggèrent que la connaissance du contenu pédagogique joue un rôle prépondérant dans la façon dont les enseignantes et enseignants utilisent la technologie. Leurs connaissances sont par ailleurs renforcées par des convictions professionnelles concernant l'importance de l'intermodalité ainsi que par des facteurs contextuels impliquant le soutien institutionnel et les communautés de pratique. Elles se sont toutefois avérées limitées par l'auto-efficacité réduite des enseignantes et enseignants et leurs croyances pédagogiques relativement à l'influence de la technologie sur l'apprentissage et l'engagement des étudiantes et étudiants. Cette étude s'ajoute à un corpus croissant de recherches sur la façon de soutenir les professeurs de langue dans leurs pratiques numériques.

KEYWORDS: multimodal composition, second language writing, TPACK

\section{Introduction}

"Now, everyone please go to sites.google.com," says Ryan.

Juan exclaims, "Oh this is so confusing!"

"What's wrong?" Ryan asks.

"I dunno," answers Juan. "How do I go to there?"

Ryan answers, "Just type in sites.google.com." Ryan repeats this exact

phrase several times, but Juan still seems confused. Finally, Ryan walks

over to Juan's desk and shows him how to start a new site.

"Here, click the red button on the bottom right."

Juan sighs, apparently still confused.

Especially in the field of second language writing (SLW), the scenario described above is a common one. Teachers are equipped with digital tools that enable multimodal methods for teaching composition, but they often struggle, as Ryan does, to use these tools effectively. Reasons for this include, but are not limited to, a lack of multimodal assessment literacy (Dagenais et al., 2017), the view that multimodal genres are not related to academic writing (Howell et al., 2015), and the pressure to conform to paper-based "flat" literacies (Lotherington \& Jenson, 2011). Arguably, these obstacles stem, in part, from teacher cognition, which has not been studied extensively in computerassisted language learning (CALL) teacher education (CTE) research (Chao, 2015). There is, thus, a need for a sound framework to measure SLW teacher knowledge processes and address potential gaps in teacher education.

Koehler et al. (2007) claim that using technology effectively in the classroom "requires appreciation of the complex set of interrelationships between 
artifacts, users, tools and practices" (p. 742). More specifically, teachers need to understand how technology, pedagogy, and content function dynamically within their educational context. The Technological, Pedagogical, Content Knowledge (TPACK) framework (Mishra \& Koehler, 2006; Koehler \& Mishra, 2009), which addresses these relationships, has become increasingly popular in education research over the past several years. Yet, few studies have investigated TPACK's potential for guiding professional development at the tertiary level (Mourlam et al., 2016), and even fewer have examined it within the context of second language (L2) writing (SLW) instruction. Drawing from insights in multidisciplinary TPACK research across educational contexts, this case study examines how three in-service SLW teachers apply their TPACK during a digital multimodal portfolio module in an undergraduate composition course.

\section{Literature Review}

\section{TPACK: What It Is, How to Find It, and How It Grows}

The TPACK framework provides a theoretical foundation to explain the integrated knowledge a teacher should possess to implement technology in a way that leads to meaningful learning (Mishra \& Koehler, 2006). It is situated in practice, shaped by context, and expressed through interactions between its core constructs (content, pedagogy, and technology). These constructs are distributed across seven knowledge domains (see Figure 1). Content knowledge (CK) for L2 instruction involves a teacher's knowledge of the target language and its culture (Van Olphen, 2008). Pedagogical knowledge (PK) comprises general (i.e., not discipline-specific) comprehension of instruction methods. Technological knowledge (TK) includes a teacher's understanding of the functional use of digital technologies in both professional and personal contexts. Technological content knowledge (TCK), in language teaching, involves using technology to represent cultural and linguistic knowledge (Van Olphen, 2008). Pedagogical content knowledge (PCK) is the transformation of subject-specific representations "to make the content more comprehensible to students" (Graham et al., 2012, p. 532). Technological pedagogical knowledge (TPK) involves knowing how to adapt technology to suit a pedagogical approach. Taken together, TPACK is considered the "thoughtful interweaving of all three key sources of knowledge" (Koehler \& Mishra, 2006, p. 1029). 


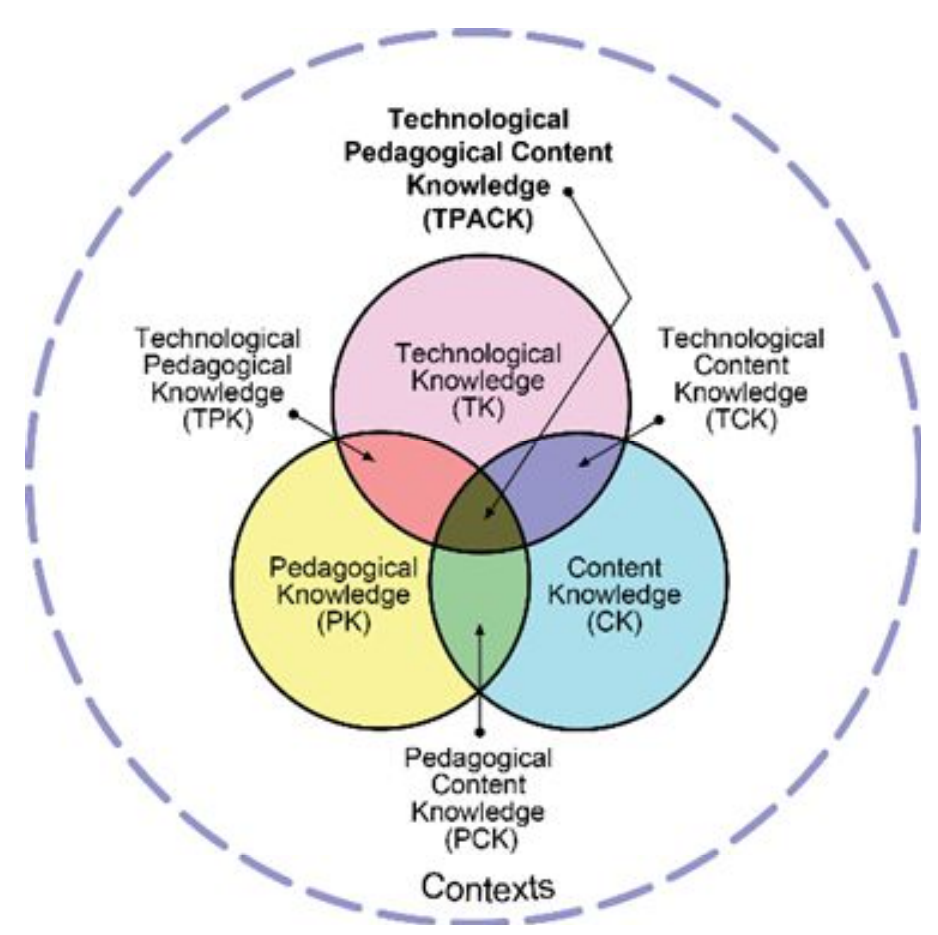

Figure 1. TPACK Framework (reproduced by permission of the publisher, (c) 2012 by tpack.org). TPACK = Technological Pedagogical Content Knowledge.

Characteristics of TPACK. Several authors have suggested how to recognize TPACK in practice. Niess (2011) and Niess et al. (2009) distinguish four central areas of TPACK development: curriculum and assessment (using technology to plan and evaluate student learning); learning (using technology to present course content and guide student use of technology); teaching (technology-focused content delivery, course design, professional development, and creation of a technology-friendly learning environment); and access (making technology easy for all students, including learners with diverse needs).

Jaipal-Jamani and Figg (2015) suggest that teachers with high levels of TPACK have a repertoire of technology-enhanced activity types (see Harris \& Hoffer, 2009) that align with content-based models of teaching (see Joyce et al., 2004). These teachers orient their planning around pedagogical goals, analyzing learning outcomes to identify whether "factual, conceptual, metacognitive, or procedural" knowledge is targeted (p. 145), then selecting the tech-focused activity and model of teaching most suited to the achievement of that outcome. Mina (2019) concurs that teachers who are critical users of technology tend to frame their technology use around pedagogical goals.

Teacher reasoning and TPACK. Beliefs and attitudes are central influences in teachers' pedagogical reasoning. In an ethnography of three elementary school teachers, Saudelli and Ciampa (2016) discovered that the teacher with the greatest enthusiasm for mobile technologies experienced the most success using them, despite having the least experience. In another 
study, Yang et al. (2014) reported a discrepancy between teacher beliefs and behaviors respective to certain practices, such as offering individualized feedback. They attribute this to the teachers' lack of knowledge of their students (or PCK). Other studies have cited inconsistencies between self-reports and actual teacher technology practices (e.g., Heitink et al., 2016; Koh \& Chai, 2016), which is why triangulation of multiple data sources is generally preferred in TPACK research (Debbagh \& Jones, 2018; Harris et al., 2010; Lee \& Kim, 2014).

The not-so-hidden context. One crucial element of the TPACK framework is the context in which it is applied (Porras-Hernández \& Salinas-Amescua, 2013). Research suggests that it is not "the isolated learning activity that affects learning, but the way the teacher structures learning activities in a learning environment," including use of technology, articulation of curriculum, classroom management practices, and student interaction (Heitink et al., 2016, p. 71). Koh et al. (2014) concluded in their study on collaborative lesson design that TPACK is positively influenced by the intrapersonal context and, in contrast, constrained by cultural/institutional factors.

\section{TPACK and L2 Education}

The small but growing body of scholarship pertaining to TPACK in language education is, in fact, a microcosm of the larger body of TPACK research. In the field of language teaching, the TPACK framework has been applied to explore the impact of digital tools on student success (Muhamad, 2014), student perception of teachers' technology use (Tseng, 2018), the characterization of TPACK within the context of CALL (Debbagh \& Jones, 2018; Rahmany et al., 2014) and World Languages (Van Olphen, 2008), and the exploration of individual differences in technology implementation (Szeto \& Cheng, 2017). In SLW, TPACK has served as a framework to evaluate specific digital tools (Sujee et al., 2015), to draw connections between teachers' pedagogical knowledge and beliefs pertaining to multimodal feedback (Yang et al., 2014), and to design collaborative online writing courses (H. C. Tai et al., 2015).

However, few L2 studies address the technology-focused needs of SLW instructors, and even fewer directly target teacher knowledge. Among those that do, there is agreement that L2 educators need to move beyond viewing technology as a peripheral or supplementary aspect of language instruction; instead, a paradigmatic shift is needed to restructure composition pedagogy to meet the requirements of the digital age (Dzekoe, 2017; Elola \& Oskoz, 2016; Jenkins, 2009).

\section{Reflection and Multimodal Composition}

Multimodality is a fundamental affordance of writing in the digital age. It supports the writing proficiency development of language learners by facilitating awareness of multiple semiotic modes that enrich linguistic connections (Guichon \& Cohen, 2016; Nelson, 2006). It has also been shown to 
promote an elevated sense of self-efficacy (Choi \& Yi, 2016), learner agency (Ajayi, 2009), creativity (Archer, 2006), affect (Thesen, 2001), and self-expression (Shin \& Cimasko, 2008). The reflective portfolio is a digital genre that commonly appears in university writing curricula, which is why it was chosen as the portal through which to observe teachers' technology integration practices in this study. Considering TPACK's emphasis on situated knowledge and the importance of situated practice in SLW and CALL contexts, TPACK is well suited for an exploration of the following research questions:

Research Question 1 (RQ1): How do SLW teachers use their knowledge when they integrate technological resources into their teaching practices?

Research Question 2 (RQ2): How do TPACK's knowledge domains interact with each other to support or constrain SLW teachers' use of technology?

\section{Methodology}

\section{Educational Context}

This qualitative multiple-case study was conducted at the Writing Program of a Southwestern university in the United States. The Writing Program delivers the university's first-year composition courses to domestic and international students as part of the general education curriculum. English 106, 107, and 108 are semester-long courses offered to international students. These three courses comprise a sequence for which the latter two (107 and 108) are required and the former (106) is supplementary, for students who need extra support with their language skills before moving on to the normal curriculum.

The courses for domestic and international students are bound by a common set of teaching principles, curricular goals, and a unified mission. However, the curriculum differs between domestic and international writing courses regarding the latter's explicit focus on language learning. One binding element between all writing courses is the reflective portfolio, administered as the final project. The parameters of the portfolio are set by writing program administrators, but teachers choose how to execute the project in their own classes. Each teacher in this study interpreted the portfolio as a digital multimodal composition.

\section{Participants}

Three in-service university SLW teachers, Ryan, Kayla, and Amber, were semi-randomly recruited for this study, based on responses to a preliminary 
departmental survey. Every SLW teacher who, in the preliminary survey, expressed interest in participating was recruited for this study. The only requirement was that participants would be teaching a digital reflective portfolio unit during the time of data collection. The first three teachers to respond to the recruitment email who also met the aforementioned requirement became the participants of this study. All participants taught in the same writing program. Ryan and Kayla taught the English 106 course, and Amber taught the English 108 course. All three teachers were either former or current students in the same L2 acquisition and teaching PhD program. Amber and Kayla were doctoral students at the time of the study, and Ryan had recently graduated from this program.

\section{Data Collection}

Data were collected during the portfolio unit in each teacher's course. An online TPACK survey, completed at the beginning of the study, provided a baseline interpretation of each teacher's TPACK. Observations and instructional materials offered insight into the teachers' classroom practices, and reflective interviews, held directly after each observation, allowed teachers to describe the reasoning processes driving their practices.

TPACK survey. This Likert-type survey was derived from Basert et al.'s (2015) empirically validated TPACK English as a Foreign Language (EFL) instrument, which was adapted from Schmidt et al.'s (2009) original TPACK survey. The survey used in this study was further adapted to suit an SLW context (see Appendix A).

Observations. Each teacher's portfolio-related lessons were observed. Kayla's and Amber's modules included four lessons, but due to time constraints, Ryan only had three lessons in his module. To make teachers more comfortable, observations were not recorded. Instead, notes were taken using S. J. D. Tai's (2015) TPACK-In-Action observation instrument.

Instructional materials. To achieve a holistic view of teacher behavior, course materials from the portfolio module were shared, and I was added as an observer (i.e., without an administrative role) to the online course site. This allowed me to see the content posted by the teacher but limited my ability to observe any interactions involving students.

Interviews. Following each observed class, a 10- to 15-min semistructured reflective interview occurred between myself and the teacher. During the interview, based on Harriset et al.'s (2010) TPACK Interview Protocol, I discussed my observation notes with the teacher and elicited their responses. 


\section{Data Analysis}

Drawing from a relativist ontological epistemology, this study employed constructivist grounded theory (Charmaz, 2000, 2001), which promotes the idea that meaning is co-constructed between the researcher and participants and is based on inductive data collection, emergent themes, constant comparison techniques, and a [semi-]literary writing style (Mills et al., 2006).

Initially, data were organized by category (i.e., content, instruction, and reflection) and reviewed for preliminary themes concerning technology use, which evolved into a set of "technology strategies." During the following phase, the data from each category were divided into units of instruction. For content, a unit of instruction was one distinct, complete resource (e.g., one PowerPoint presentation, one webpage from the learning management system [LMS], or one PDF handout). For instruction (observations) and reflection (interviews), a unit of instruction was an episode of classroom activity (or description thereof) involving one main pedagogical move (e.g., lecture, class discussion, group activity, homework explanation).

To address RQ1 (How do SLW teachers use their knowledge when they integrate technological resources into their teaching practices?), units of instruction from content and observations were coded for

1. Learning activity type (CK), using the Secondary English Language Arts Learning Activity Types (referred to in this study as SLA LATs; Young et al., 2011); and

2. English Language Learner (ELL) pedagogical strategies (PK), using Harris et al.'s (2013) TPACK-based taxonomy of teaching strategies for ELL learners.

Example SLA LATs are provided in Table 1, and sample ELL strategy codes are provided in Table 2. Subcodes emerged from these main categories through a flexible open-coding process.

Table 1

Excerpt: Secondary English Language Arts Learning Activity Types (SLA LATs)

\begin{tabular}{lllll}
\hline $\begin{array}{l}\text { Reading Process } \\
\text { Activity Types }\end{array}$ & $\begin{array}{l}\text { Writing Process } \\
\text { Activity Types }\end{array}$ & $\begin{array}{l}\text { Language-Focused } \\
\text { Activity Types }\end{array}$ & $\begin{array}{l}\text { Oral Speaking/ } \\
\text { Performance } \\
\text { Activity Types }\end{array}$ & $\begin{array}{l}\text { Listening/Watching } \\
\text { Activity Types }\end{array}$ \\
\hline Pre-Reading & Pre-Writing & Language Inquiry & $\begin{array}{l}\text { Oral Speaking/ } \\
\text { Performance }\end{array}$ & Listening/Watching \\
-Activating/ & -Brainstorming/ & -Language & -Speaking/Speech & -Listening Actively \\
$\begin{array}{l}\text { Generating } \\
\text { Knowledge }\end{array}$ & Listing & Exploration & &
\end{tabular}




\begin{tabular}{|c|c|c|c|c|}
\hline $\begin{array}{l}\text { Reading Process } \\
\text { Activity Types }\end{array}$ & $\begin{array}{l}\text { Writing Process } \\
\text { Activity Types }\end{array}$ & $\begin{array}{l}\text { Language-Focused } \\
\text { Activity Types }\end{array}$ & $\begin{array}{l}\text { Oral Speaking/ } \\
\text { Performance } \\
\text { Activity Types }\end{array}$ & $\begin{array}{l}\text { Listening/Watching } \\
\text { Activity Types }\end{array}$ \\
\hline & $\begin{array}{l}\text {-Webbing/ } \\
\text { Clustering/Semantic } \\
\text { Mapping }\end{array}$ & $\begin{array}{l}\text {-Language } \\
\text { Awareness }\end{array}$ & $\begin{array}{l}\text {-Performance/ } \\
\text { Production }\end{array}$ & $\begin{array}{l}\text {-Multimodal/ } \\
\text { Multimedia } \\
\text { Interaction }\end{array}$ \\
\hline
\end{tabular}

Table 2

English Language Learner (ELL) Pedagogical Strategies

\begin{tabular}{|c|c|}
\hline ELL Pedagogical Strategies & Example Codes \\
\hline Communicate Clearly & "and I'm going to explain how that affects your final grade." \\
\hline $\begin{array}{l}\text { Make Content } \\
\text { Understandable }\end{array}$ & Amber draws a graph of the scores on the board. \\
\hline $\begin{array}{l}\text { Check Students' } \\
\text { Understanding }\end{array}$ & $\begin{array}{l}\text { He asks students to go to the course Kahoot page, where there are review } \\
\text { questions about the portfolio project instructions. }\end{array}$ \\
\hline Elicit Students' Responses & $\begin{array}{l}\text { "Alright, who remembers this questionnaire that you took the first-or second } \\
\text { week of class? Where do you think that would fit on the planning sheet?" }\end{array}$ \\
\hline Demonstrate/Model & She then shows them how to add a title to their Google doc. \\
\hline $\begin{array}{l}\text { Encourage Interpersonal } \\
\text { Communication }\end{array}$ & $\begin{array}{l}\text { Ryan greets every student as they walk in the room; then, he walks around to } \\
\text { each seated student to greet them individually. }\end{array}$ \\
\hline $\begin{array}{l}\text { Group Students to Assist } \\
\text { Their Learning }\end{array}$ & $\begin{array}{l}\text { He assigns one criterion from the rubric per group and asks them to discuss } \\
\text { what that would look like for this class; they should summarize it in their own } \\
\text { words. }\end{array}$ \\
\hline $\begin{array}{l}\text { Promote Cross-Cultural } \\
\text { Awareness }\end{array}$ & One student has written his name and title in Chinese on the Google site. \\
\hline
\end{tabular}

Content and instruction data were analyzed to compare how technology was used in classroom activities (TCK) and how pedagogical strategies complemented technology use (TPK). For both the content and instruction data, each pedagogical move was classified as one or more SLA LATs and coded for ELL teaching strategies (PCK). Then, the tech-enhanced LATs and strategies were compared with the general data to infer any patterns between teacher knowledge and technology integration.

It is important to note that the content analysis scrutinized only what was built into each resource. Classroom use of content (unless noted in observation field notes), or any inference about how the material might be used, was not included. Also, because teachers admittedly did not design all their own content, only technologies embedded into a task, not those used in document design, were considered. Conversely, observation data focused primarily on classroom activity, not content. Themes discovered during the initial data organization process were synthesized into a set of technology strategies focused directly on technology use rather than activity type or pedagogical strategy (see Table 3). 
Table 3

Technology Strategies

\begin{tabular}{|c|c|c|}
\hline Technology Strategies & Descriptor & Example Codes \\
\hline Functional Knowledge (TK) & $\begin{array}{l}\text { Procedural knowledge of the basic } \\
\text { operations of a tech tool }\end{array}$ & $\begin{array}{l}\text { She clicks the PowerPoint to } \\
\text { advance the hidden text. }\end{array}$ \\
\hline Student Support (TPK) & $\begin{array}{l}\text { Advising students on how to use } \\
\text { technology; encouraging student } \\
\text { use of technology; helping students } \\
\text { resolve tech-related problems on } \\
\text { their own devices }\end{array}$ & $\begin{array}{l}\text { One student says, "Oops I deleted } \\
\text { one!" Kayla responds, "Do control } \\
\text { Z-or Command Z." }\end{array}$ \\
\hline Classroom Management (TPK) & $\begin{array}{l}\text { Organizing students or student } \\
\text { work; facilitating classroom } \\
\text { procedures }\end{array}$ & $\begin{array}{l}\text { She explains that she will go into } \\
\text { their folders and check that they } \\
\text { have highlighted a section, and if } \\
\text { they haven't, they will not get points } \\
\text { for this activity. }\end{array}$ \\
\hline Tech-Focused Instruction (TPK) & $\begin{array}{l}\text { Lecturing/presenting information } \\
\text { about technology or where to find } \\
\text { something online }\end{array}$ & $\begin{array}{l}\text { She explains that students should } \\
\text { go to the LMS and download the } \\
\text { Goal Organizer. }\end{array}$ \\
\hline Strategizing (TPK) & $\begin{array}{l}\text { Sequencing or coordinating the use } \\
\text { of different technologies }\end{array}$ & $\begin{array}{l}\text { She suggests that if there are a lot } \\
\text { of screenshots, they might want to } \\
\text { download it as a PDF. }\end{array}$ \\
\hline Problem Solving (TPK) & $\begin{array}{l}\text { Resolving a tech-related issue } \\
\text { involving instruction (classroom } \\
\text { technology rather than students' } \\
\text { devices) }\end{array}$ & $\begin{array}{l}\text { She shows how students can copy/ } \\
\text { paste from the planner but forgets } \\
\text { to paste as plain text. "Ooops-but } \\
\text { get rid of that," she says and } \\
\text { deletes, then repeats the paste } \\
\text { function, this time as plain text. }\end{array}$ \\
\hline $\begin{array}{l}\text { Demonstrate/Model Technology } \\
\text { (TPACK) }\end{array}$ & $\begin{array}{l}\text { Guiding students through step- } \\
\text { by-step processes involving } \\
\text { technology; showing how to do } \\
\text { something digital with course } \\
\text { content }\end{array}$ & $\begin{array}{l}\text { She shows another student } \\
\text { portfolio example, also on Adobe } \\
\text { Spark, and explains how the } \\
\text { organization is different from the } \\
\text { other example. }\end{array}$ \\
\hline Hybridizing (TPACK) & $\begin{array}{l}\text { Blending high-tech and low-tech } \\
\text { activities and content }\end{array}$ & $\begin{array}{l}\text { She shows a worksheet, } \\
\text { downloaded from the LMS, on the } \\
\text { screen. Then she hands out strips } \\
\text { of paper with outcomes written on } \\
\text { them to each pair of students, and } \\
\text { they match the outcomes to the } \\
\text { correct goal from the worksheet. }\end{array}$ \\
\hline
\end{tabular}

Note. LMS = learning management system; PDF = portable document format.

To account for reliability, this coding process was repeated for all data 1 month after the original coding procedure. Each set of codes was compared and harmonized. Each teacher was analyzed individually, and emergent themes were compared across teachers. The resulting themes were then triangulated with teachers' self-reports (e.g., reflection) to answer RQ2 (How do knowledge domains interact with each other to support or constrain SLW teach- 
ers' use of technology?). Reflective interviews were transcribed and parsed for segments in which (a) the teachers explained the reasoning behind their decisions to implement, or not to implement, a technology, or (b) general commentary reflected attitudes and beliefs about technology. Prominent trends arising from this analysis were compared across teachers.

\section{Findings}

The following section evaluates each teacher's TPACK before amalgamating the data to extract more general themes. This section first introduces each teacher, then outlines what they did with technology (also see Appendix B) and how they did it. The section culminates with an exploration of why each teacher used technology in the way that they did.

\section{Ryan's Story}

Ryan began each lesson greeting students while taking attendance online. As he entered attendance, he addressed each student individually for an informal chat and emotional check-in ("Do you wanna talk? You ok? You can come chat if you want to-my door's always open"). He walked around the room, shaking everyone's hand. His interest in his students' lives illustrated his attempts not only to encourage interpersonal communication but also to promote intercultural awareness in his classes, as the following excerpt from his observations shows:

Ryan is standing in front of the computer while taking attendance.

As he calls out names, he asks each student how they are feeling on a scale of $1-5,5$ being the worst. They are all saying 4 and 5 .

Ryan shrugs and says, "Weekend effect," probably because it's a Monday. He continues, "How was your weekend, Juan? What did you do this weekend?"

Juan says, "I slept in like every day."

Ryan responds, "Sounds like you didn't want to face your exam!"

This small-talk attendance routine, observed during each lesson, was supported by the details of Ryan's interviews, during which he discussed the importance of honouring students' identities, improving teacher-student relationships, and engaging students with course content. He argued that promoting intercultural awareness by allowing the first language (L1) in the classroom "adds to the conversation" and "allows [students] to have, authentic buy-in" to the content. He asserted that "not allowing what is essentially their entire lives outside the classroom in the classroom is a huge problem." With this and other statements and actions, he validated their identities in many ways, including digitally. 


\section{Ryan's Intersecting Knowledge Domains}

Ryan focused mainly on Language Analysis LATs in equal amounts for both digital and general instruction, and he targeted Writing Process LATs in both digital and general content. A total of $32 \%$ of all pedagogical strategies in Ryan's content were tech-enhanced. During instruction, he averaged 20 techenhanced pedagogical strategies per lesson, more than the other two teachers. Ryan used the same two strategies (Make Content Understandable and Elicit Students' Responses) in similar amounts in both his tech-enhanced and general content. Make Content Understandable was also the most common strategy in his tech-enhanced instruction, and it was the second most common strategy in his general instruction.

Ryan's Technology Strategies. Ryan used a total of 33 technology strategies during his classes. Of this, the most popular were Tech-Focused Instruction $(n=11)$ and Student Support $(n=9)$.

\section{Ryan - Tech Strategies During Instruction LATs}

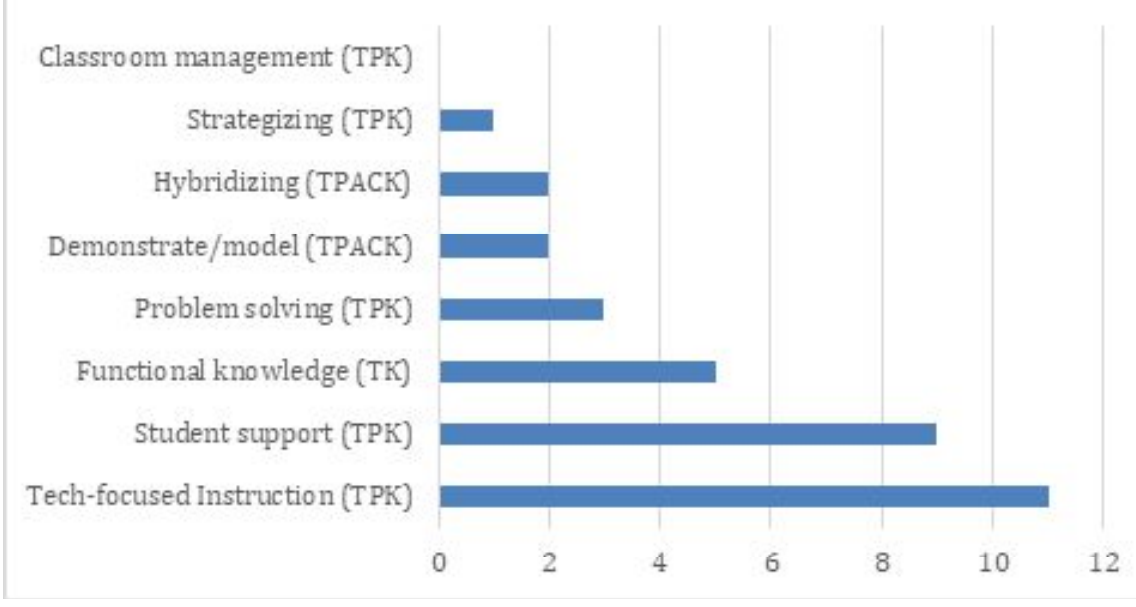

Figure 2. Ryan's Technology Strategies

Note. LATs = Learning Activity Types; TPACK = Technological Pedagogical Content Knowledge.

The beliefs influencing Ryan's use of technology were twofold. On one hand, he emphasized the value of digital composition for students and expressed gratitude for the institutional support of multimodal composition. He explained that, over the past few years, multimodal composition practices have been increasingly infused into the Writing Program curriculum at the administrative level, which has made certain technologies easier to implement. These beliefs are countered, on the other hand, by his assertion that he is "not the techiest of teachers." He described himself as a teacher who "embrace[s] these sort of minimal service level technologies in the classroom" but who also values the "analog experience." The following rationale 
explains why he preferred to hybridize, or blend, digital and analog practices in the classroom:

I think variation is a really important thing, especially for language learners, and you know, air land and sea, so you're coming at them in all different ways ... In a fifty minute class, it's so important that they are on task the whole time, and while I let them have their personal technology, um, for better or for worse, sometimes, cutting that off allows them to focus. And the small groups, getting up and working in small groups, increases accountability.

As the quote suggests, Ryan's pedagogical goals were generally focused on responding to student needs, and technology use was involved in that, though not central to it. Ryan used various digital and nondigital strategies to "test the waters," to check in with students on both cognitive and affective levels. For example, he judged students' emotional and verbal reactions using a low-stakes quiz with Kahoot clicker software to determine that students were at the very early stages of understanding the portfolio assignment. During the technology demonstration of the final lesson, he walked around the room, checking each students' laptop to ensure they had followed instructions. Ryan's tech-focused pedagogical strategies were aimed at guiding students to produce multimodal compositions, which he believed bridged their daily activities, thus, positively influencing affect:

There's an affective improvement. I think that when you're asking them in the language learning classroom to participate in these multimodal composition practices they already do outside of the classroom, that has a sort of comforting impact which is, you know, obviously great for language learning.

Ryan's decision to use Google Sites as the required software for the portfolio was grounded in the belief that it was useful for "their job and in other classes moving forward." He recounted learning about this new software during a bimonthly collaborative meeting with other SLW teachers, illustrating the influence of a community of practice on TPACK development:

So, I decided to try this Google site [approach] this semester. Um, so Adrienne had done it before, and she shared with me some of this material, which is why you see some of Adrienne's fingerprints on a lot of this stuff, 'cause during the last meeting I was like "ok I wanna do this."

In the diagnostic survey, Ryan was the most confident across all knowledge domains (see Appendix C), and this confidence appeared in the other data presented here. Overall, he expressed profound knowledge of his students and his academic discipline (PCK), and this governed the way he integrated technology into his classes. It led him to explore new tools for 
multimodal composition, to integrate intercultural/interpersonal dimensions to his technology use, and to respond to students' needs by demonstrating digital tools. Ryan's pedagogical knowledge also led him to hybridize technology in the classroom, providing variation to maintain student engagement. Finally, he credits institutional expectations and interactions with colleagues as contextual factors that encouraged his use of technology. In contrast, his self-classification as not a "techy" teacher (TK), coupled with his belief that student engagement can be negatively impacted by technology, perhaps fueled his self-proclaimed minimalistic approach to technology use in the classroom.

\section{Kayla's Story}

Kayla's story is rooted in her general beliefs and attitudes about technology and pedagogy. While she acknowledged the importance of digital literacy "in theory," she had decided to simplify the portfolio project as much as possible by requesting that each portfolio be a single Google doc without hyperlinks. She was unconvinced that her students were prepared to use complex technologies, and she believed that mandating high-tech portfolios (i.e., hyperlinked documents or websites) would bring complications and increase her overall stress.

Another line of reasoning behind her decision to simplify the digital aspect of the project reflected the institutional context in which she taught. This was Kayla's first semester teaching English 106, a course that had been developed by other teachers and administrators. Instructors teaching English 106 for the first time were advised to use the premade course. Kayla cited the limited time allotted for the portfolio module in the premade course (only three to four lessons) as a major impediment to experimenting with new technologies. In addition, during collaborative meetings with other English 106 teachers, colleagues had warned her that students need a lot of time for the portfolio, and most of that time, she had assumed, was for the design of their portfolio websites. Consequently, she "just took that out of the equation because it takes too long," and she did not find it "super important."

Finally, she indicated that she did not feel well-equipped to teach multimodal composition:

I don't think I'm qualified to do that. I don't know anything about it. I might model or do some of it like-just on my own, but it's not because that's my background or that I'm pedagogically trained to connect those things.

She elaborated that she "could do a quick demo of Google drive," which she thought was an "effective tool" for students to learn, but overall, she did not "know how to best utilize [technology] in class." This lack of self-efficacy 
contrasted her behavior in class, and it was likely a limiting factor in her TPACK.

\section{Kayla's Intersecting Knowledge Domains}

While Kayla's content focused on Writing Process and Language Analysis LATs, her instruction targeted Writing Process and Reading Process LATs. Like Ryan, Kayla used the same LATs in similar amounts for both digital and general content and instruction. Overall, $16 \%$ of the ELL pedagogical strategies built into Kayla's content were tech-enhanced. The same strategies (Make Content Understandable and Elicit Students' Responses) were also prevalent in both her general content and her tech-enhanced content. During instruction, Kayla averaged 18 tech-enhanced pedagogical strategies per lesson, slightly less than Ryan but more than Amber. The most common strategies applied during tech-enhanced instruction were the same as for her tech-enhanced content (Make Content Understandable and Elicit Students' Responses). Make Content Understandable was the second most popular strategy in her general instruction, appearing after Communicate Clearly. While they employed similar strategies for both tech-enhanced and general content, both Kayla and Ryan used Communicate Clearly more frequently in general than in techenhanced instruction.

Kayla's Technology Strategies. Of all the teachers, Kayla employed the greatest number of technology strategies $(n=60)$ during her lessons. The technology strategies used most frequently were Tech-Focused Instruction $(n=17)$, Student Support $(n=9)$, and Demonstrate/Model Technology $(n=8)$.

\section{Kayla - Tech Strategies During Instruction LATs}

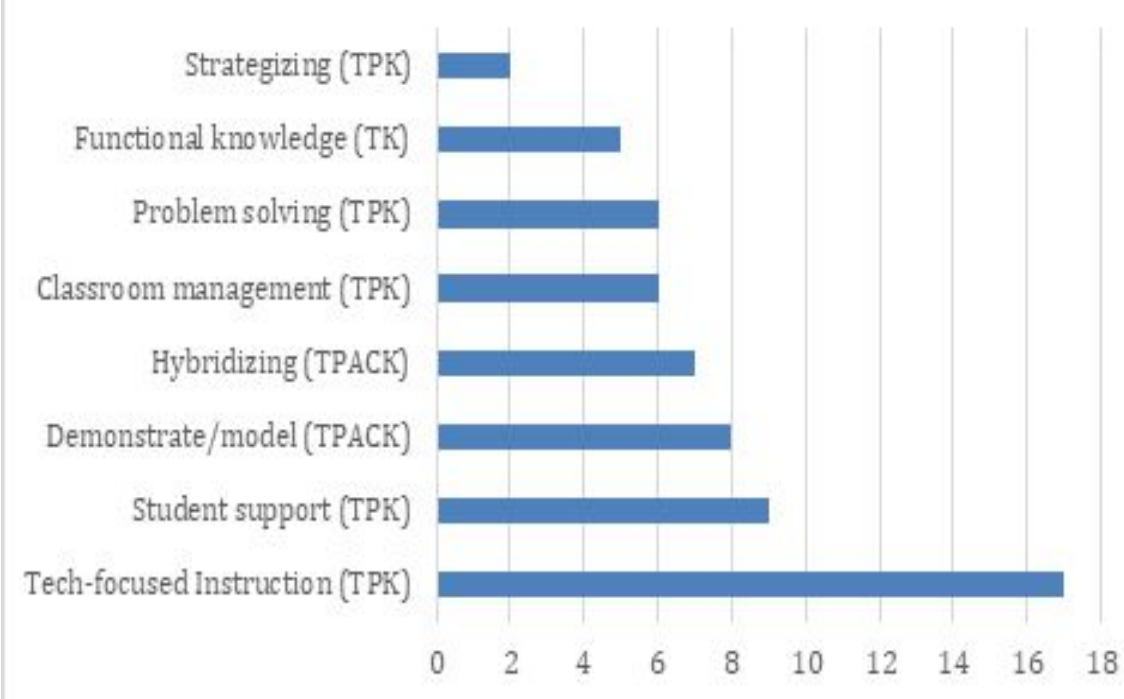

Figure 3. Kayla's Technology Strategies

Note. LATs = Learning Activity Types; TPACK = Technological Pedagogical Content Knowledge. 
Kayla distinguished her technology use from that of the other two teachers by using it for classroom management. In contrast with Ryan, who conducted his technology demonstration near the end of the module, she scaffolded her demonstrations throughout the module, to ensure that "there were no excuses and to make sure that the technology was understood by everybody." She also recalled examining students' drafts on Google docs before one lesson to arrange peer review partners:

I had planned the pairs and the groups for the peer review ahead of time, but then I checked [Google Drive] before class to see who had actually done the work - like, who had a full draft ready, and I basically asked the five people in the class who didn't have sufficient drafts to use the time in class to write [instead of doing peer reviews] ...

Kayla used technology to support her students' editing efforts by demonstrating, for instance, how to use the search function within a Google doc to find and change all second person "you/yours" to the third person and to correct errors in apostrophe use. She also explained how the search function is different for different operating systems ("If you have a Mac you can do command F. If you don't have a Mac, you can do control F"). She attributed her hybridization of digital and nondigital resources to the SLW teacher collaborative meetings. During one meeting, an activity involving both online documents and slips of paper had been introduced, and Kayla decided to try it in her lesson. This is another indication of how a community of practice can influence a teacher's method of selecting and deploying instructional content.

The fact that Kayla did not discuss her ability to support students' use of technology, a strategy observed regularly during her classes, might indicate that she was not aware of how much technological assistance she had offered. That, coupled with her self-characterization as unconfident with multimodal pedagogy, contrasted the rich data showing her expertise in guiding students to produce multimodal texts. In addition, Kayla assessed all her knowledge domains, and especially her technological knowledge, as lower than either of her colleagues in the diagnostic TPACK survey (see Appendix C). Like Ryan, Kayla's technology use was shaped in part by her professional context, including institutional expectations, collaboration with other teachers, and the limited time assigned for the portfolio module.

\section{Amber's Story}

What resonated throughout Amber's classes was the individual attention she gave her students. Amber had no problem sitting in an empty desk next to a student to chat about an assignment while others were working, and students invariably lined up to talk to her after each class. Her lessons were less structured than the other teachers'; she allowed more digressions based on 
negotiations with her students. In general, she took a reflective approach to teaching:

I think talking about the [writing] process - their own personal processes, is really important, for myself as well. And whatever I do with them, I think about in my own life.

It was this reflective interaction, not technology, that guided Amber's approach.

Amber understood the value of technology in writing, though she did not find it essential. She reasoned, "you can still analyze [texts] without a computer, but [using technology] brings you closer to real world writing." During class, Amber emphasized conventional, rather than digital, composition processes, like brainstorming, freewriting, text analysis, and drafting. Although her lessons were generally low-tech, she introduced an array of tech-enhanced instructional content on the LMS. She had hoped that students would complete the in-class writing tasks and "take it home and build it into their portfolios," using her tech-enhanced content.

\section{Amber's Intersecting Knowledge Domains}

Amber focused primarily on Writing Process LATs both in her content and instruction, and during both digital and general activities, and $14 \%$ of the pedagogical strategies embedded into Amber's content were tech-enhanced. The most frequent strategy for both tech-enhanced and general content was Make Content Understandable. During instruction, Amber averaged 12 techenhanced pedagogical strategies per move, fewer than the other two teachers. The most common strategies used in both her tech-enhanced and general instruction were Make Content Understandable and Elicit Students' Responses. Like the other two teachers, Amber used Communicate Clearly more during general instruction than tech-enhanced instruction. Amber often used technology in her content to model multimodal composition, and during instruction, she used technology more interactively, to elicit student responses.

Amber's Technology Strategies. Amber used the fewest technology strategies of all three teachers $(n=23)$. Analysis revealed that Functional Knowledge $(n=7)$ and Tech-Focused Instruction $(n=6)$ were the most common. 


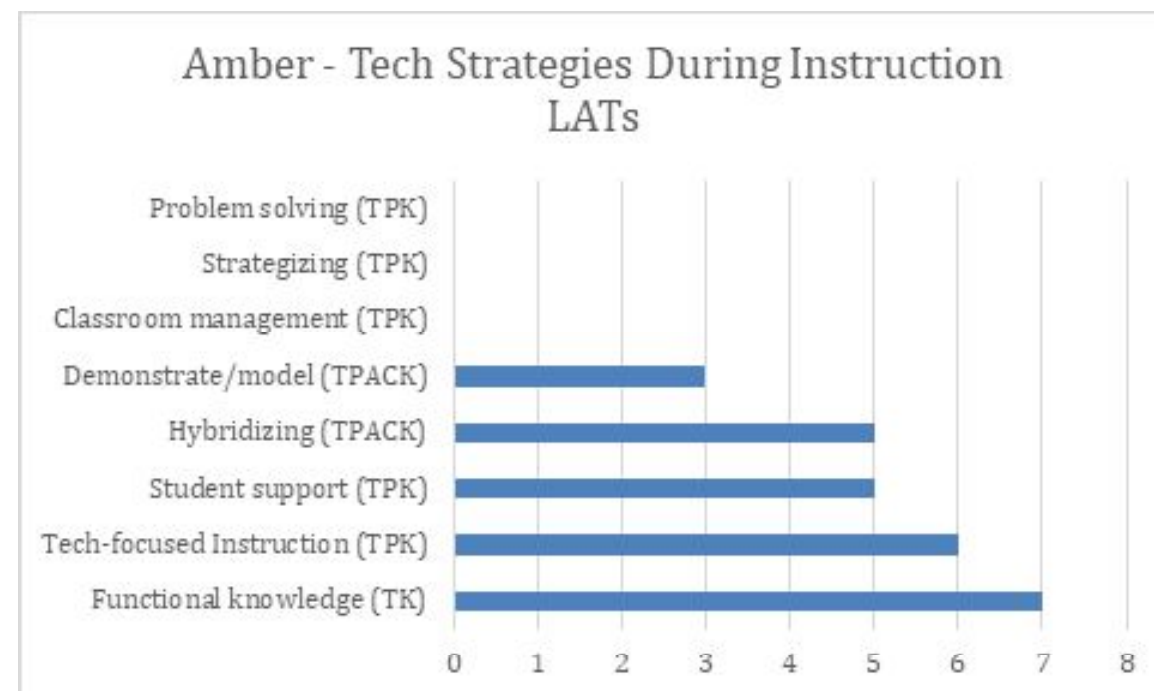

Figure 4. Amber's Technology Strategies

Note. LATs $=$ Learning Activity Types. TPACK $=$ Technological Pedagogical Content Knowledge.

Amber used PowerPoint as a reflexive tool to guide her through each class. She explained, "it's a lot of work for me, but it also makes the flow of things easier, and I try not to keep it like a lecture. I like to put in all the activities, and it guides me [through the lesson]." When asked why she decided to copy/paste content from the digital textbook into her slides instead of simply using the textbook in class, Amber answered that it was easier to add everything to PowerPoint than constantly transition from the screen to her notes. Second, apart from the portfolio module, she did not often invite her students to use laptops during class. Finally, she commented,

we really have not used [the digital textbook] a lot ... I bet at least

half of them would have no idea where to find [it]. It's like the instructions would take up half the time. This way's just easier.

Amber credits her use of Adobe Spark to the Writing Program, stating, "I show the Adobe examples because that's what they'd already included-the Writing Program team" (in shared online folders). While she liked the Adobe suite, she was ambivalent about which tools her students used to create their portfolios. Because she preferred to "open things up," she modelled portfolio examples from a range of software programs, in contrast to the other two teachers, who requested portfolios from specific software platforms. She mused, "I could give them a template [for the digital portfolio], but that is so boring, and why restrict them that much?" Such comments highlighted her enthusiasm to support her students' autonomy and creative use of technology.

Because she expected her students to do most of their multimodal composing at home, much of Amber's content involved technology-embedded tasks. Her interactive style of lecturing through PowerPoint perhaps explained why 
she focused on Listening/Watching LATs during most of her lessons. Finally, her flexible approach to technology integration aligned with her strategy of modelling a variety of digital portfolios during lessons.

Although she did not infuse technology into her lectures as much as the other two teachers, Amber spent valuable time developing tech-enhanced content, and she included a wide range of tech-based resources in her LMS site. She also evaluated her Technological Knowledge, as well as her Content and Pedagogical Knowledge, highly in the TPACK diagnostic survey (see Appendix C). However, Amber's reliance on tech-enhanced content rather than tech-enhanced instruction implies her TCK was perhaps stronger than her TPK. Like the other teachers, Amber's selection of tech-enhanced content was also partly inspired by her colleagues.

\section{Discussion}

Overall, the teachers who participated in this study demonstrated strong levels of TPACK in the content they used and the lessons they taught. Each teacher approached technology integration with a unique style, and in each case, these diverse styles were guided by pedagogical reasoning, fueled by pedagogical beliefs. However, it was also their pedagogical beliefs and professional contexts that ultimately limited these teachers' TPACK.

\section{The Interacting Knowledge Domains of SLW Teachers}

SLA LATs. Writing Process LATs were the most common for all teachers in both digital and general content. This indicates the teachers' ability to use technology to represent the most pertinent content of their field, which is an indication of strong TPACK (Jaipal-Jamani \& Figg, 2015). It is also noteworthy that each teacher used similar proportions of learning activity types for tech-enhanced content and instruction as they did for general content and instruction. This could suggest that their content knowledge (CK, selection of learning activities) was driven by their pedagogical knowledge (PK, learning goals) rather than their technological knowledge (TK, digital mode of representation).

ELL Strategies. The pedagogical strategies employed most frequently in the general content for all three teachers were Make Content Understandable, Elicit Student Responses, and Communicate Clearly. Remarkably, two of these three strategies were also most common in tech-enhanced content for all three teachers. The strategies most frequently applied during techenhanced instruction were Make Content Understandable (for all three teachers) and Elicit Student Responses (for Kayla and Amber).

Although technology was used during instruction mainly to enhance student understanding and to encourage dialogic interaction, there was a slight preference to clarify or repair communication directly without using 
technology. This is logical during face-to-face instruction, where physical presence affords direct communication. Overall, there was slightly more variation in the employment of pedagogical strategies for digitally enhanced teaching than for digitally enhanced content. The greater effect of technology on pedagogical strategy use than on the selection of learning activities may indicate that a stronger relationship exists between the teachers' pedagogical knowledge (PK) and their technological knowledge (TK) than between their content knowledge (CK) and technological knowledge (TK).

Technology Strategies. Each teacher regularly guided students to use technology via Tech-Focused Instruction. However, the teachers employed these technology strategies with distinct styles. For example, Kayla guided student use of technology by giving students categorical choices (e.g., option A or option B) for how to use technology whereas Amber left instructions open (e.g., "this is one way you could do it, but find a way that works well for you"). In certain instances, such as Kayla's use of Student Support, teachers seemed to implement technology strategies without direct metacognitive awareness of so doing. Other times, such as Ryan's facilitation of Tech-Focused Instruction in a culturally sensitive way, the teachers seemed very aware of how they wielded technology strategies.

\section{Teacher Reasoning and TPACK}

Interviews and contextual data suggest that it is not simply their most frequent actions but also those acts that expose the underlying themes driving teacher practices that unveil the nuanced landscape of each teachers' TPACK. For Ryan, pedagogical beliefs concerning variation and learner engagement arose as themes that justified his technology integration practices. Kayla's TPACK appeared primarily in her classroom management strategies, as well as her unplanned and undescribed actions, offering technical support and advising on how to use technology strategically. Amber believed in nurturing students' creative use of technology, which inspired her to model a variety of digital software options for portfolio construction. The common strand across these three teachers, which supports this study's findings regarding their instruction and content, confirms that their choices about technology use were driven by their pedagogical, more than their content, knowledge.

TPACK Support and Constraint in SLW. The teachers' behaviors were elementally impacted by their beliefs, attitudes, and professional contexts. The most common motivating belief was that digital multimodal composition is important for students' future academic and professional careers. In general, each teacher expressed concern for their students' future academic and professional success, to which multimodality was undoubtedly a contributing factor. The teachers' concern for their students, including knowing when they were anxious or struggling with course content (PCK), inspired their creative uses for technology. 
Contextual factors played a mostly positive role in the teachers' technology integration. Each teacher attributed some aspect of their technologyfocused instruction to the mandatory "collaboratives" with the other SLW teachers. This community of practice served as a melting pot of ideas that guided their practice. The institutional support provided by the Writing Program in the form of learning outcomes and the obligatory portfolio project further encouraged the use of technology in the classroom. However, Kayla and Amber both expressed confusion over several institutional requirements, and Kayla was apprehensive to veer away from the prepackaged course design.

Finally, while all teachers acknowledged the importance of cultivating their students' digital literacy, they were sometimes hesitant to emphasize it due to personal beliefs about learners or learning. Ryan argued that technology might negatively impact student engagement while Kayla and Amber feared that it would take too much time and effort to implement. This is a reminder that multimodality can be challenging for both students and teachers (Archer, 2006; Molle \& Prior 2008).

These findings, when taken together, offer valuable insight into the support SLW teachers may need to develop their TPACK. First, teachers may be more motivated to learn about technologies that are already embedded into their practice rather than entirely new tools. Second, TPACK development can be effectively mediated at the collegial and institutional levels. Teachers can work together to share and develop technology-enhanced content and lesson plans rather than doing it on their own, and institutional processes can guide teachers to focus on using certain technologies for clearly defined purposes. Students' digital literacy skills could also be cultivated and supported at the institutional level to lessen the burden for teachers.

There is also a need to demystify multimodal pedagogy, to present it, instead, as something tangible, familiar, and grounded in practice. If inservice SLW teachers understand that they already possess TPACK and that multimodal pedagogy is already within their teaching practice, they might be more enthusiastic to pursue it further. Instead of viewing multimodal pedagogy as an elusive and erudite concept, it might be helpful to show teachers how it is firmly rooted in their professional lives, both inside and outside the classroom.

\section{Limitations and Future Directions}

While this study has yielded some valuable insights, there are several limitations to note. Regarding the ELL pedagogical strategies, some codes were impossible to assess without recordings of the observation (e.g., Pausing with Sufficient Wait Time; Use of Body Language). Perhaps a more fine-grained measurement tool could overcome this obstacle. Also, the analysis accounted only for in-class activities. Consideration of homework and out-of-class 
assignments was minimal. In addition, except for the rubrics provided as instructional content, this study did not analyze teachers' assessment practices. Future SLW TPACK research could take a closer look at multimodal assessment practices related to digital portfolio projects. Finally, the use of technology was guided by the nature of the portfolio assignment. For other kinds of assignments, technology may be used differently by the same teachers. Future studies could explore SLW teachers' TPACK pertaining to other multimodal assignment genres.

\section{Conclusion}

This study investigated SLW teacher knowledge and technology integration, using the TPACK framework. It sought to discover how teachers applied their TPACK during a digital portfolio module, and how their TPACK was supported or constrained by various cognitive and contextual factors. While each teacher displayed a unique style of technology use, several common themes arose in the data.

First, the fact that the teachers' learning activities and ELL strategies were nearly congruent for both their tech-enhanced and general content and instruction indicates that their PCK, rather than their TK, likely governed their TPACK. Furthermore, the teachers used similar technology strategies with various approaches and levels of metacognitive awareness. Finally, teacher beliefs and their professional contexts were strong influencing factors on how teachers interacted with their TPACK. Interestingly, the teachers' support for digital multimodal composition, seen as imperative to their students' futures, contradicted their pedagogical belief that technology can be disadvantageous to learning. Ultimately, the belief that they were not techsavvy or well prepared to deliver multimodal composition pedagogy, despite evidence to the contrary, also constrained their TPACK. The role of context, specifically the institutional support that nurtured the creation of communities of practice among SLW teachers, enhanced these teachers' TPACK, though institutional prescriptivism also sometimes limited their autonomy and constrained their practice.

To assist SLW teachers in developing their TPACK, it is essential to understand how extant technological, pedagogical, and content knowledge domains operate and intersect. It is vital to address teachers' needs before designing professional development and teacher education programs. By exploring the TPACK of SLW teachers, this study contributes to the body of existing research on how to support language teachers in their digitally mediated practices. Furthermore, it provides valuable insight for in-service SLW teachers, relating their cognitive processes to multimodal composition pedagogy. 


\section{Acknowledgement}

I would like to offer my special thanks to the teachers who volunteered their time, wisdom, and materials for this study. Participants make research possible. Assistance provided through the Linda Waugh SLAT Research Funds, University of Arizona, was also greatly appreciated.

\section{The Author}

Nicole Schmidt, PhD, Second Language Acquisition and Teaching, is currently an instructional designer at the University of Arizona. Her research focuses on teacher knowledge and critical digital literacies in the second language writing classroom. She has taught composition and English as a Second and Foreign Language in the United States, Japan, the Netherlands, and Spain.

\section{References}

Ajayi, L. (2009). English as a second language learners' exploration of multimodal texts in a junior high school. Journal of Adolescent \& Adult Literacy, 52(7), 585-595. https://doi. org/10.1598/JAAL.52.7.4

Archer, A. (2006). A multimodal approach to academic "literacies": Problematising the visual/ verbal divide. Language and Education, 20(6), 449-462. https://doi.org/10.2167/le677.0

Baser, D., Kopcha, T. J., \& Ozden, M. Y. (2015). Developing a technological pedagogical content knowledge (TPACK) assessment for preservice teachers learning to teach English as a foreign language. Computer Assisted Language Learning, 29(4), 749-764. https://doi.org/10.1080/ 09588221.2015 .1047456

Chao, C. (2015). Rethinking transfer: Learning from CALL teacher education as consequential transition. Language Learning \& Technology, 19(1), 102-118. Retrieved from https://www. 1ltjournal.org/

Charmaz, K. (2000). Grounded theory: Objectivist and constructivist methods. In N. Denzin \& Y. Lincoln (Eds.), Handbook of qualitative research (2nd ed., pp. 507-536). Thousand Oaks, CA: Sage. https://doi.org/10.4135/9781473999350

Charmaz, K. (2001). Qualitative interviewing and grounded theory analysis. In J. Gubrium \& J. Holstein (Eds.), Handbook of interview research: Context and method (pp. 675-694). Thousand Oaks, CA: Sage. https://doi.org/10.4135/9781412973588.n39

Choi, J., \& Yi, Y. (2016). Teachers' integration of multimodality into classroom practices for English language learners. TESOL Journal, 7(2), 304-327. https://doi.org/10.1002/tesj.204

Dagenais, D., Toohey, K., Bennett Fox, A., \& Singh, A. (2017). Multilingual and multimodal composition at school: ScribJab in action. Language and Education, 31(3), 263-282. https://doi. org/10.1080/09500782.2016.1261893

Debbagh, M., \& Jones, W. M. (2018). Examining English language teachers' TPACK in oral communication skills teaching. Journal of Educational Multimedia and Hypermedia, 27(1), 43-62. Retrieved from https://www.learntechlib.org/primary/p/178510/

Dzekoe, R. (2017). Computer-based multimodal composing activities, self-revision, and L2 acquisition through writing. Language Learning \& Technology, 21(2), 73-95. Retrieved from https:// www.lltjournal.org/

Elola, I., \& Oskoz, A. (2016). Supporting second language writing using multimodal feedback. Foreign Language Annals, 49, 58-74. https://doi.org/10.1111/flan.12183

Graham, C. R., Borup, J., \& Smith, N. B. (2012). Using TPACK as a framework to understand teacher candidates' technology integration decisions. Journal of Computer Assisted Learning, 28(6), 530-546.

Guichon, N., \& Cohen, C. (2016). Multimodality and CALL. In F. Farr \& L. Murray (Eds.), The Routledge handbook of language learning and technology (pp. 509-521). London, England: Routledge. Retrieved from https://www.routledge.com 
Harris, J., Grandgenett, N., \& Hofer, M. (2010, March). Testing a TPACK-based technology integration assessment rubric. In D. Gibson \& B. Dodge (Eds.), Proceedings of Society for Information Technology \& Teacher Education International Conference 2010 (pp. 3833-3840). Chesapeake, VA: Association for the Advancement of Computing in Education (AACE). Retrieved from http://www.editlib.org/p/33978

Harris, J., Grandgenett, N., \& Hofer, M. (2012). Testing an instrument using structured interviews to assess experienced teachers' TPACK. In C. D. Maddux, D. Gibson, \& R. Rose (Eds.), Research highlights in technology and teacher education 2012 (pp. 1-15). Chesapeake, VA: Society for Information Technology \& Teacher Education (SITE). Retrieved from http://site.aace.org/

Harris, J., \& Hofer, M. (2009, March). Instructional planning activity types as vehicles for curriculum-based TPACK development. In I. Gibson, R. Weber, K. McFerrin, R. Carlsen, \& D. Willis (Eds.), Proceedings of SITE 2009-Society for Information Technology \& Teacher Education International Conference (pp. 4087-4095). Charleston, SC: AACE. Retrieved from https://www.learntechlib.org/primary/p/31298/

Harris, J., Van Olphen, M., \& Hofer, M. (2013, March). Incorporating knowledge of students systematically into TPACK-based instruction: An illustration. In R. McBride \& M. Searson (Eds.), Proceedings of SITE 2013-Society for Information Technology E Teacher Education International Conference (pp. 5054-5061). New Orleans, LA: AACE. Retrieved from https:// www.learntechlib.org/primary/p/48933/

Heitink, M., Voogt, J., Verplanken, L., Van Braak, J., \& Fisser, P. (2016). Teachers' professional reasoning about their pedagogical use of technology. Computers \& Education, 101, 70-83. https://doi.org/10.1016/j.compedu.2016.05.009

Howell, E., Reinking, D., \& Kaminski, R. (2015). Writing as creative design: Constructing multimodal arguments in a multiliteracies framework. Journal of Literacy and Technology, 16(1), 2-36. Retrieved from http://www.literacyandtechnology.org/

Jaipal-Jamani, K., \& Figg, C. (2015). The framework of TPACK-in-practice: Designing content-centric technology professional learning contexts to develop teacher knowledge of technology-enhanced teaching (TPACK). In C. Angeli \& N. Valanides (Eds.), Technological Pedagogical Content Knowledge (pp. 137-163). Boston, MA: Springer. https://doi. org/10.1007/978-1-4899-8080-9_7

Jenkins, H. (2009). Confronting the challenges of participatory culture: Media education for the 21st century. Cambridge, MA: MIT Press. https://doi.org/10.7551/mitpress/8435.001.0001

Joyce, B., Weil, M., \& Calhoun, E. (2004). Models of teaching (7th ed.). New York: Pearson.

Koehler, M. J., \& Mishra, P. (2009). What is Technological Pedagogical Content Knowledge? Contemporary Issues in Technology and Teacher Education, 9(1), 60-70. Retrieved from https:// www.learntechlib.org/p/29544/

Koehler, M. J., Mishra, P., \& Yahya, K. (2007). Tracing the development of teacher knowledge in a design seminar: Integrating content, pedagogy and technology. Computers $\mathcal{E}$ Education, 49(3), 740-762. https://doi.org/10.1016/j.compedu.2005.11.012

Koh, J. H. L., \& Chai, C. S. (2016). Seven design frames that teachers use when considering Technological Pedagogical Content Knowledge (TPACK). Computers \& Education, 102, 244257. https://doi.org/10.1016/j.compedu.2016.09.003

Koh, J. H. L., Chai, C. S., \& Tay, L. Y. (2014). TPACK-in-Action: Unpacking the contextual influences of teachers' construction of Technological Pedagogical Content Knowledge (TPACK). Computers $\mathcal{E}$ Education, 78, 20-29. https://doi.org/10.1016/j.compedu.2014.04.022

Lee, C. J., \& Kim, C. (2014). An implementation study of a TPACK-based instructional design model in a technology integration course. Educational Technology Research and Development, 62(4), 437-460. https://doi.org/10.1007/s11423-014-9335-8

Lotherington, H., \& Jenson, J. (2011). Teaching multimodal and digital literacy in L2 settings: New literacies, new basics, new pedagogies. Annual Review of Applied Linguistics, 31, 226-246. https://doi.org/10.1017/S0267190511000110 
Mishra, P., \& Koehler, M. J. (2006). Technological Pedagogical Content Knowledge: A framework for teacher knowledge. Teacher's College Record, 108(6), 1017. https://doi.org/10.1111/j.14679620.2006.00684.x

Mills, J., Bonner, A., \& Francis, K. (2006). The development of constructivist grounded theory. International Journal of Qualitative Methods, 5(1), 25-35. https://doi. org/10.1177/160940690600500103

Mina, L. W. (2019). Analyzing and theorizing writing teachers' approaches to using new media technologies. Computers and Composition, 52, 1-16. https://doi.org/10.1016/j.compcom.2019.01.002

Molle, D., \& Prior, P. (2008). Multimodal genre systems in EAP writing pedagogy: Reflecting on a needs analysis. TESOL Quarterly, 42(4), 541-566. https://doi.org/10.1002/j.1545-7249.2008. tb00148.x

Mourlam, D., Meacham, S., \& Herring, M. C. (2016). TPACK development in higher education. In P. Mishra, M. J. Koehler, \& M. C. Herring (Eds.), Handbook of Technological Pedagogical Content Knowledge (TPACK) for educators (pp. 217-234). Routledge. https://doi. org/10.4324/9781315771328

Muhamad, N. A. B. (2014). Investigating the roles of motivation and Technological Pedagogical Content Knowledge (TPACK) in computer-mediated-communication (CMC) speaking skills instruction. International Journal of Applied Linguistics and English Literature, 3(2), 112-130. Retrieved from http://www.journals.aiac.org.au/index.php/IJALEL/index

Nelson, M. E. (2006). Mode, meaning, and synaesthesia in multimedia L2 writing. Language Learning and Technology, 10(2), 56-76. Retrieved from https://www.lltjournal.org

Niess, M. L. (2011). Investigating TPACK: Knowledge growth in teaching with technology. Journal of Educational Computing Research, 44(3), 299-317. https://doi.org/10.2190/ec.44.3.c

Niess, M. L., Ronau, R. N., Shafer, K. G., Driskell, S. O., Harper, S. R., Johnston, C., Browning, C., Özgün-Koca, S., \& Kersaint, G. (2009). Mathematics teacher TPACK standards and development model. Contemporary Issues in Technology and Teacher Education, 9(1), 4-24. Retrieved from https://www.citejournal.org/

Porras-Hernández, L. H., \& Salinas-Amescua, B. (2013). Strengthening TPACK: A broader notion of context and the use of teacher's narratives to reveal knowledge construction. Journal of Educational Computing Research, 48(2), 223-244. https://doi.org/10.2190/ec.48.2.f

Rahmany, R., Sadeghi, B., \& Chegini, A. S. (2014). Normalization of CALL and TPACK: Discovering teachers' opportunities and challenges. Journal of Language Teaching $\mathcal{E}$ Research, 5(4). https://doi.org/10.4304/jltr.5.4.891-900

Saudelli, M. G., \& Ciampa, K. (2016). Exploring the role of TPACK and teacher self-efficacy: An ethnographic case study of three iPad language arts classes. Technology, Pedagogy and Education, 25(2), 227-247. https://doi.org/10.1080/1475939x.2014.979865

Schmidt, D. A., Baran, E., Thompson, A. D., Mishra, P., Koehler, M. J., \& Shin, T. S. (2009). Technological Pedagogical Content Knowledge (TPACK): The development and validation of an assessment instrument for preservice teachers. Journal of Research on Technology in Education, 42(2), 123-149. https://doi.org/10.1080/15391523.2009.10782544

Shin, D. S., \& Cimasko, T. (2008). Multimodal composition in a college ESL class: New tools, traditional norms. Computers and Composition, 25(4), 376-395. https://doi.org/10.1016/j.compcom.2008.07.001

Sujee, E., Engelbrecht, A., \& Nagel, L. (2015). Effectively digitizing communication with Turnitin for improved writing in a multilingual classroom. Journal for Language Teaching, 49(2), 11-31. https://doi.org/10.4314/jlt.v49i2.1

Szeto, E., \& Cheng, A. Y. N. (2017). Pedagogies across subjects: What are preservice teachers' TPACK patterns of integrating technology in practice? Journal of Educational Computing Research, 55(3), 346-373. https://doi.org/10.1177/0735633116667370 
Tai, H. C., Pan, M. Y., \& Lee, B. O. (2015). Applying Technological Pedagogical and Content Knowledge (TPACK) model to develop an online English writing course for nursing students. Nurse Education Today, 35(6), 782-788.

Tai, S. J. D. (2015). From TPACK-in-action workshops to classrooms: CALL competency developed and integrated. Language Learning $\mathcal{E}$ Technology, 19(1), 139-164. https://doi.org/10.31274/ etd-180810-3577

Thesen, Lucia (2001). Modes, literacies and power: A university case study. Language and Education 15(2-3), 132-145. https://doi.org/10.1080/09500780108666806

Tseng, J. J. (2018). Exploring TPACK-SLA interface: Insights from the computer-enhanced classroom. Computer Assisted Language Learning, 31(4), 390-412. https://doi.org/10.1080/09588221 .2017.1412324

Van Olphen, M. (2008). TPCK: An integrated framework for educating world language teachers. In American Association of Colleges for Teacher Education (Eds.), Handbook of Technological Pedagogical Content Knowledge (TPCK) for educators (pp. 107-128). New York: Routledge for the American Association of Colleges for Teacher Education. https://doi. org/10.4324/9781315771328

Yang, C. Y. C., Chao, J. Y. C., \& Huang, C. K. (2014). The role of EFL teacher beliefs in web-supported writing instruction and feedback practices. 國立彰化師範大學文學院學報 [National Changhua University of Education (NCUE) Journal of Humanities], 9, 101-121. Retrieved from http://ir.ncue.edu

Young, C. A., Hofer, M., \& Harris, J. (2011, February). Secondary English language arts learning activity types. Retrieved from College of William and Mary, School of Education, Learning Activity Types Wiki: http://activitytypes.wm.edu/SecEngLangArtsLearningATs-Feb2011.pdf

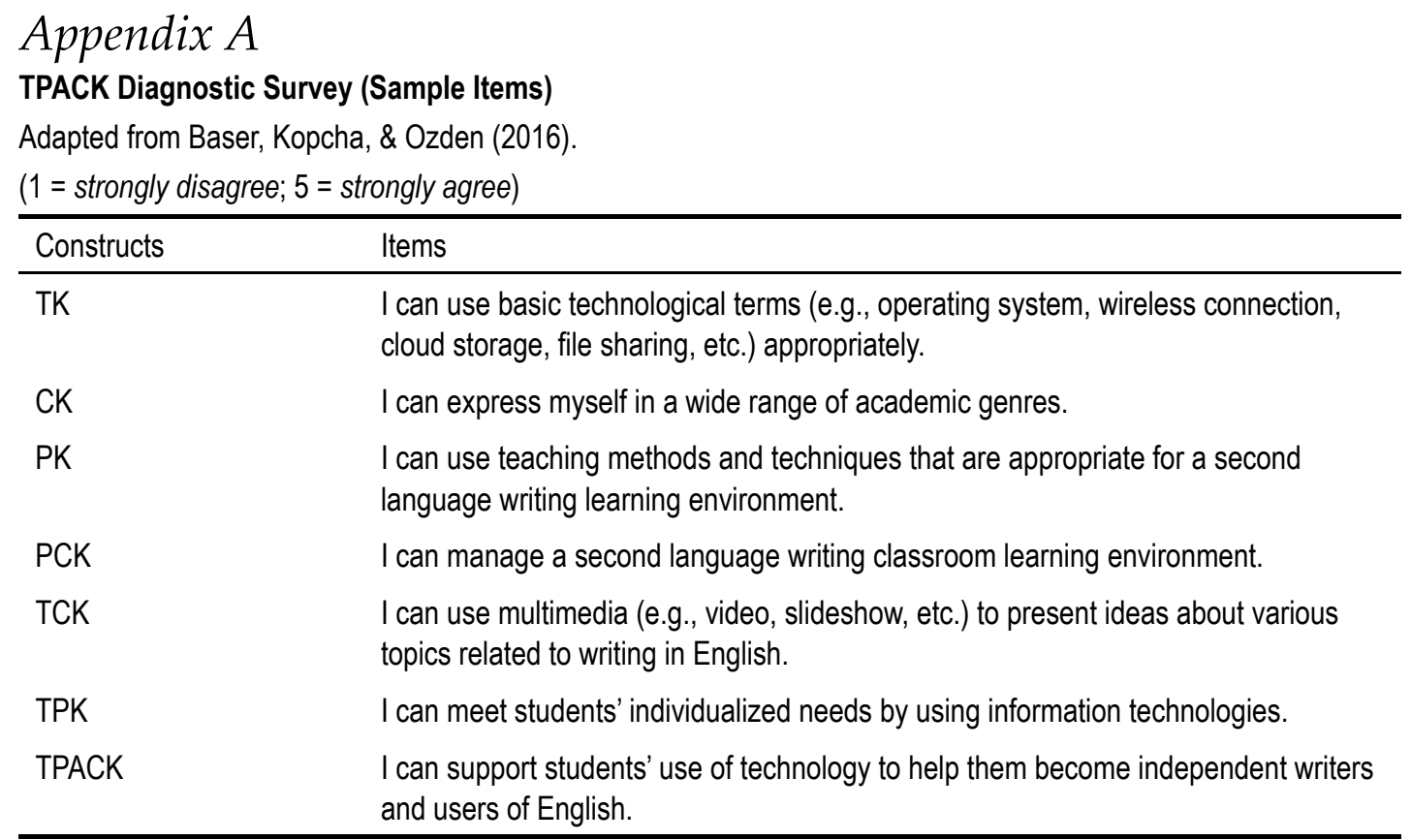

Note. TPACK = Technological Pedagogical Content Knowledge. 
Appendix $B$

TPACK for LATs and ELL Strategies

Table B1

Ryan's SLA LATs: Content

\begin{tabular}{lcc}
\hline SLA LATs & All Content $(n=10)$ & Tech-Enhanced Content $(n=6)$ \\
\hline Reading Process & $19 \%$ & $23 \%$ \\
Writing Process & $43 \%$ & $52 \%$ \\
Language-Focused & $19 \%$ & $9 \%$ \\
Speaking/Performance & $5 \%$ & $2 \%$ \\
Listening/Watching & $14 \%$ & $14 \%$ \\
\hline
\end{tabular}

Table B2

Ryan's SLA LATs: Instruction

\begin{tabular}{lcc}
\hline SLA LATs & All Instruction $(n=75)$ & Tech-Enhanced Instruction $(n=72)$ \\
\hline Reading Process & $24 \%$ & $25 \%$ \\
Writing Process & $20 \%$ & $21 \%$ \\
Language-Focused & $25 \%$ & $26 \%$ \\
Speaking/Performance & $9 \%$ & $8 \%$ \\
Listening/Watching & $21 \%$ & $19 \%$ \\
\hline
\end{tabular}

Ryan's ELL Pedagogical Strategies

\begin{tabular}{lcc}
\hline ELL Pedagogical Strategies & All Content $(n=147)$ & All Instruction $(n=204)$ \\
\hline Communicate clearly & $19 \%$ & $26 \%$ \\
Make Content Understandable & $32 \%$ & $18 \%$ \\
Check Students' Understanding & $12 \%$ & $18 \%$ \\
Elicit Students' Responses & $22 \%$ & $13 \%$ \\
Demonstrate/Model & $10 \%$ & $6 \%$ \\
Encourage Interpersonal & $4 \%$ & $12 \%$ \\
Communication & $1 \%$ & $3 \%$ \\
Group Students to Assist Their & $19 \%$ & $3 \%$ \\
Learning & Table B4 & \\
Promote Cross-Cultural Awareness & Ryan's Tech-Enhanced ELL Pedagogical Strategies & \\
\hline & Tech-Enhanced Content $(n=47)$ & Tech-Enhanced Instruction $(n=60)$ \\
\hline ELL Pedagogical Strategies & $6 \%$ & $15 \%$ \\
\hline Communicate clearly & $32 \%$ & $44 \%$ \\
Make Content Understandable & $6 \%$ & $10 \%$ \\
Check Students' Understanding & $34 \%$ & $16 \%$ \\
Elicit Students' Responses & & \\
\hline
\end{tabular}




\begin{tabular}{|c|c|c|}
\hline ELL Pedagogical Strategies & Tech-Enhanced Content $(n=47)$ & Tech-Enhanced Instruction $(n=60)$ \\
\hline Demonstrate/Model & $17 \%$ & $7 \%$ \\
\hline $\begin{array}{l}\text { Encourage Interpersonal } \\
\text { Communication }\end{array}$ & $4 \%$ & $7 \%$ \\
\hline $\begin{array}{l}\text { Group Students to Assist Their } \\
\text { Learning }\end{array}$ & $0 \%$ & $1 \%$ \\
\hline Promote Cross-Cultural Awareness & $0 \%$ & $1 \%$ \\
\hline \multirow{2}{*}{\multicolumn{3}{|c|}{$\begin{array}{c}\text { Table B5 } \\
\text { Kayla's SLA LATs: Content }\end{array}$}} \\
\hline & & \\
\hline SLA LATs & All Content $(n=8)$ & Tech-Enhanced Content $(n=3)$ \\
\hline Reading Process & $23 \%$ & $22 \%$ \\
\hline Writing Process & $35 \%$ & $44 \%$ \\
\hline Language-Focused & $40 \%$ & $30 \%$ \\
\hline Speaking/Performance & $0 \%$ & $0 \%$ \\
\hline Listening/Watching & $2 \%$ & $4 \%$ \\
\hline \multicolumn{3}{|c|}{ Table B6 } \\
\hline \multicolumn{3}{|c|}{ Kayla's SLA LATs: Instruction } \\
\hline SLA LATs & All Instruction $(n=138)$ & Tech-Enhanced Instruction $(n=135)$ \\
\hline Reading Process & $25 \%$ & $25 \%$ \\
\hline Writing Process & $35 \%$ & $36 \%$ \\
\hline Language-Focused & $20 \%$ & $21 \%$ \\
\hline Speaking/Performance & $4 \%$ & $4 \%$ \\
\hline Listening/Watching & $16 \%$ & $15 \%$ \\
\hline \multicolumn{3}{|c|}{ Table B7 } \\
\hline \multicolumn{3}{|c|}{ Kayla's ELL Pedagogical Strategies } \\
\hline ELL Pedagogical Strategies & All Content $(n=81)$ & All Instruction $(n=296)$ \\
\hline Communicate clearly & $19 \%$ & $29 \%$ \\
\hline Make Content Understandable & $32 \%$ & $22 \%$ \\
\hline Check Students' Understanding & $12 \%$ & $17 \%$ \\
\hline Elicit Students' Responses & $22 \%$ & $14 \%$ \\
\hline Demonstrate/Model & $10 \%$ & $8 \%$ \\
\hline $\begin{array}{l}\text { Encourage Interpersonal } \\
\text { Communication }\end{array}$ & $4 \%$ & $8 \%$ \\
\hline $\begin{array}{l}\text { Group Students to Assist Their } \\
\text { Learning }\end{array}$ & $1 \%$ & $2 \%$ \\
\hline Promote Cross-Cultural Awareness & 0 & $0 \%$ \\
\hline
\end{tabular}


Table B8

Kayla's Tech-Enhanced ELL Pedagogical Strategies

\begin{tabular}{lcc}
\hline ELL Pedagogical Strategies & Tech-Enhanced Content $(n=13)$ & Tech-Enhanced Instruction $(n=72)$ \\
\hline Communicate clearly & $0 \%$ & $11 \%$ \\
Make Content Understandable & $46 \%$ & $30 \%$ \\
Check Students' Understanding & $0 \%$ & $16 \%$ \\
Elicit Students' Responses & $46 \%$ & $21 \%$ \\
Demonstrate/Model & $8 \%$ & $13 \%$ \\
Encourage Interpersonal & $0 \%$ & $7 \%$ \\
Communication & $0 \%$ & $2 \%$ \\
Group Students to Assist Their & $0 \%$ & $0 \%$ \\
Learning & Table B9 & \\
Promote Cross-Cultural Awareness & Amber's SLA LATs: Content & \\
\hline & All Content $(n=6)$ & Tech-Enhanced Content $(n=3)$ \\
\hline SLA LATs & $19 \%$ & $13 \%$ \\
\hline Reading Process & $43 \%$ & $39 \%$ \\
Writing Process & $19 \%$ & $0 \%$ \\
Language-Focused & $0 \%$ & $0 \%$ \\
Speaking/Performance & $17 \%$ & $13 \%$ \\
Listening/Watching & Tab &
\end{tabular}

Table B10

Amber's SLA LATs: Instruction

\begin{tabular}{lcc}
\hline Amber's SLA LATs & All Instruction $(n=124)$ & Tech-Enhanced Instruction $(n=96)$ \\
\hline Reading Process & $16 \%$ & $16 \%$ \\
Writing Process & $46 \%$ & $41 \%$ \\
Language-Focused & $10 \%$ & $9 \%$ \\
Speaking/Performance & $2 \%$ & $1 \%$ \\
Listening/Watching & $28 \%$ & $33 \%$ \\
\hline
\end{tabular}

Table B11

Amber's ELL Pedagogical Strategies

\begin{tabular}{lcc}
\hline ELL Pedagogical Strategies & All Content $(n=88)$ & All Instruction $(n=345)$ \\
\hline Communicate clearly & $20 \%$ & $10 \%$ \\
Make Content Understandable & $40 \%$ & $28 \%$ \\
Check Students' Understanding & $6 \%$ & $17 \%$ \\
Elicit Students' Responses & $17 \%$ & $26 \%$ \\
Demonstrate/Model & $13 \%$ & $5 \%$ \\
Encourage Interpersonal & $3 \%$ & $12 \%$ \\
Communication & &
\end{tabular}




\begin{tabular}{lcc}
\hline ELL Pedagogical Strategies & All Content $(n=88)$ & All Instruction $(n=345)$ \\
\hline $\begin{array}{l}\text { Group Students to Assist Their } \\
\text { Learning }\end{array}$ & $1 \%$ & $2 \%$ \\
Promote Cross-Cultural Awareness & $0 \%$ & $0 \%$ \\
\hline \multicolumn{3}{c}{ Amber's Tech-Enhanced ELL Pedagogical Strategies } \\
\hline ELL Pedagogical Strategies & Tech-Enhanced Content $(n=12)$ & Tech-Enhanced Instruction $(n=49)$ \\
\hline Communicate clearly & $0 \%$ & $10 \%$ \\
Make Content Understandable & $50 \%$ & $47 \%$ \\
Check Students' Understanding & $0 \%$ & $3 \%$ \\
Elicit Students' Responses & $8 \%$ & $30 \%$ \\
Demonstrate/Model & $33 \%$ & $8 \%$ \\
Encourage Interpersonal & $8 \%$ & $1 \%$ \\
Communication & & $1 \%$ \\
Group Students to Assist Their & $0 \%$ & $1 \%$ \\
Learning & & \\
Promote Cross-Cultural Awareness & $0 \%$ & \\
\hline
\end{tabular}

Note. TPACK = Technological Pedagogical Content Knowledge; ELL = English language learners; SLA LATs = Secondary English Language Arts Learning Activity Types.

\section{Appendix C}

TPACK Diagnostic Survey Results: Likert-Type Scores

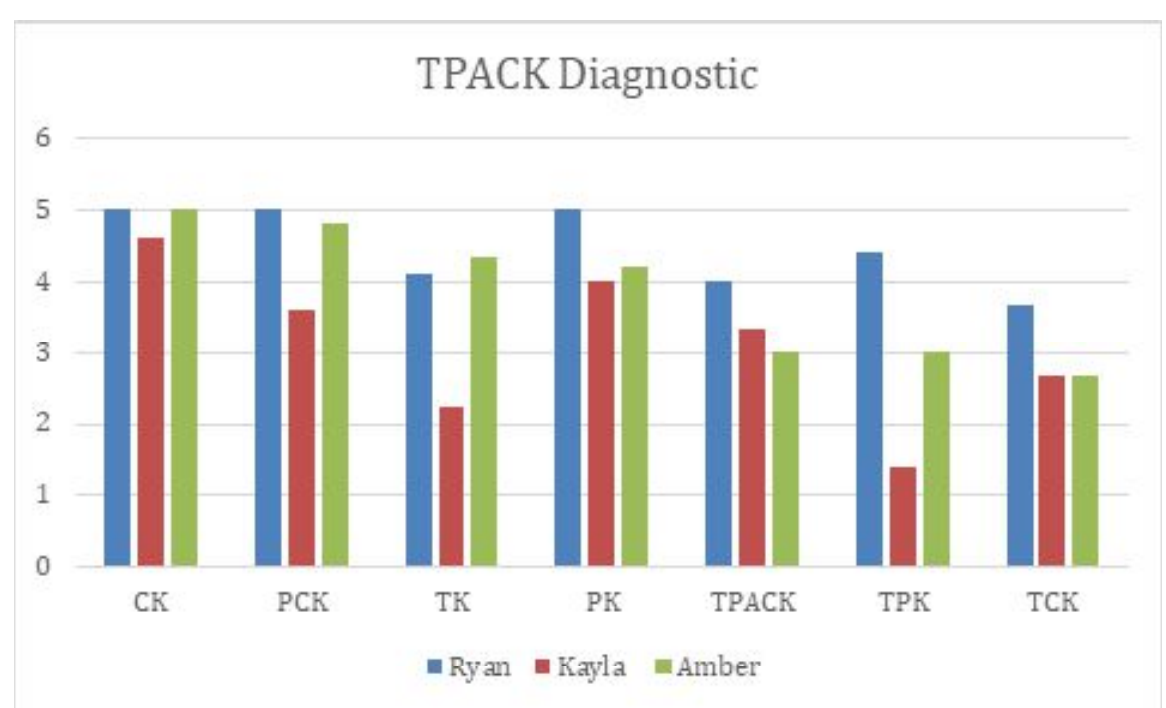

Note. TPAK $=$ Technological Pedagogical Content Knowledge. 